\title{
PRELIMINARY DESCRIPTIONS OF SOME NEW BIRDS FROM CENTRAL NEW GUINEA.
}

\author{
By the Hon. Walter rothschild, Рh.D., and Dr. E. HaRtert.
}

$\mathrm{M}^{\mathrm{H}}$ R. ALBERT S. MEEK, whose name is so well known to the readers of

Novitates Zoologicae, has been able to accompany a Dutch Exploring Expedition up the Eilanden River, a river the mouth of which lies abont a hundred miles east of the Letekwa (or Oetakwa) River and has a general trend to north-east, and to Mt. Goliath, where he collected up to elevations of above $5000 \mathrm{ft}$.

Besides the discovery of some new forms the collection is of the greatest importance from the fact that it determines the exact locality of a number of birds hitherto only known from Papuan trade-skins. Thus, for example, Pteridophora alberti, Loboparadisea sericea, and Parotia carolae carolae have been collected. We hope to give a full report on the collections later on.

\section{Paradigalla brevicauda sp. nov.}

This extraordinary new bird is in colour almost exactly like Paradigalla carunculata, being velvety black, with the head, nape, and foreneck dark metallic green, almost olive-green. In the male the whole back and scapulars are glossed with oily green; this is not seen in most skins of $P$. carunculata, but in one in the Tring Museum it is about as much developed as in most $P$. brevicauda. The median and greater upper wing-coverts are glossed with green, and the secondaries have sharply defined outer edges of a dark golden green, which colour is also to be seen on the distal portion of the inner webs, while the primaries are of a glossless black. These green outer edges to the secondaries are mostly duller and sometimes purplish in our skins of $P$. carunculata, bnt not much importance is to be attached to this difference, as the skins of $P$. brevicauda are quite fresh and properly skinned, while those of $P$. carunculata are old and remade skins.

The great and very striking difference of this new species is the short and straight, slightly emarginated tail, the central rectrices being slightly shorter, whereas in $P$. carunculata the tail is long and cuneiform, the middle tail-feathers exceeding the lateral ones by about 60 to $65 \mathrm{~mm}$. A very peculiar fact, showing evidently the line of evolution, is, that the young birds have the tail longer than the adult birds, i.e. from 35 to $40 \mathrm{~mm}$. longer !

The first two primaries are less sharply pointed and less attenuated, and the third is comparatively longer than in $P$. carunculata.

Wing $1545-160$, tail $51-54$ (against $170-180$ in $P$. carunculata), bill from end of nasal tufts (the base of the bill on the forehead being difficult to reach, on account of the wattles) $25-26$, metatarsus about $47 \mathrm{~mm}$.

The adult female resembles the male, only the crown of the head is not quite so strongly glossed, and the back has hardly any greenish gloss. Young birds are like the female, only the plumage is duller, more brownish, the tail longer, and the wattles shorter.

"Iris dark brown, feet dark vandyke brown, bill black. The lappets on the 
upper mandible (and small hidden wattle at base of lower) are creamy yellow, the rugose wattle-like skin at base of lower mandible cobalt-blne."

Type : $\delta$ ad., Mt. Goliath, Central Dutch New Guinea, 22. i. 1911. No. 5164, A. S. Meek coll.

Hab. Mt. Goliath, at elevations of not less than $5000 \mathrm{ft}$.

2. Falcinellus striatus atratus subsp. nov.

$\delta$ ad. Differs from the adult male of Falcinellus striatus striatus in being black instead of deep brown on the under-surface, and the tips of the lower ornamental side-plumes being steel-blue instead of more or less bronzy green. The beak appears to be slightly bigger, especially higher, which is more obvious in the females.

\%. Like that of $F$. s. striatus, but the upper surface, especially the tail, more olive, less rufous, and the crown generally somewhat darker rufous.

$H a b$. Mt. Goliath, at altitudes of not less than $5000 \mathrm{ft}$.

\section{Cyclopsitta blythi meeki subsp. nov.}

Similar to $C$. blythi blythi but the sides of the head less orange, paler yellow, the pectoral band well defined and of a uniform turquoise-blue, not orange-scarlet mixed with blue, abdomen and under tail-coverts paler and more apple-green. The female is like the male, bnt the colours duller. There is also, at least in the adult male, a well-defined bright yellow nuchal band, separating the orange-red of the crown from the green of the back.

Type : $\delta$ ad., Eilanden River, 10. xii. 1910. No. 5056, A. S. Meek coll.

"Iris dull yellow, bill black, feet pale yellowish green."

Hab. Eilanden River.

\section{Charmosyna stellae goliathina subsp. nov.}

Differs from $C$. stellae stellae in both sexes by having the longer upper tailcoverts dull green, instead of red.

Type: $\delta$ ad., Mt. Goliath, 27. i. $1911 . \quad$ No. 5211, A. S. Meek coll.

Hab. Mt. Goliath, Central Duteh New Guinea. 

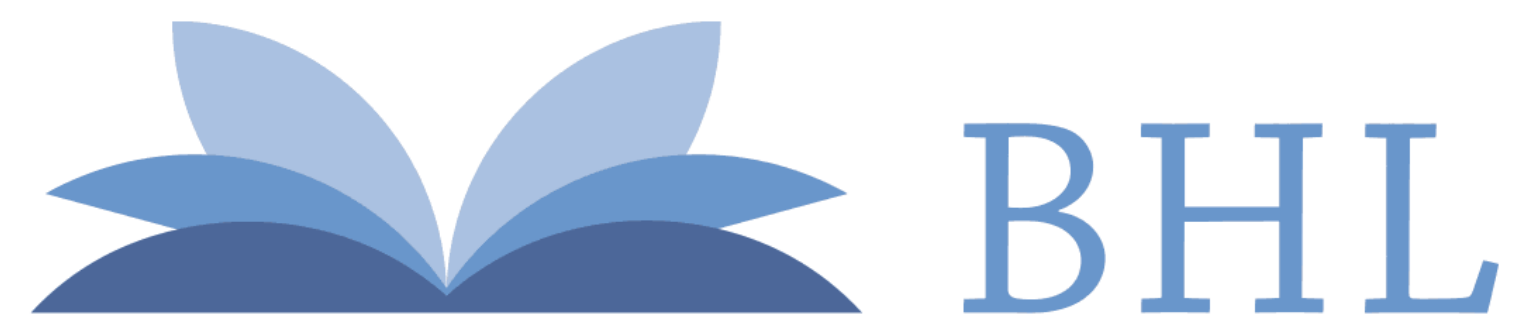

\section{Biodiversity Heritage Library}

1911. "Preliminary descriptions of some new birds from Central New Guinea." Novitates zoologicae : a journal of zoology in connection with the Tring Museum 18, 159-160. https://doi.org/10.5962/bhl.part.1693.

View This Item Online: https://www.biodiversitylibrary.org/item/22250

DOI: https://doi.org/10.5962/bhl.part.1693

Permalink: https://www.biodiversitylibrary.org/partpdf/1693

\section{Holding Institution}

Natural History Museum Library, London

\section{Sponsored by}

Natural History Museum Library, London

\section{Copyright \& Reuse}

Copyright Status: Public domain. The BHL considers that this work is no longer under copyright protection.

This document was created from content at the Biodiversity Heritage Library, the world's largest open access digital library for biodiversity literature and archives. Visit BHL at https://www.biodiversitylibrary.org. 